\title{
THE SMALL BUSINESS INVESTMENT ACT OF 1958
}

The year 1958 proved to be an important year for small business enterprises. In its last session, Congress took three significant steps long awaited by those concerned with the strength and competitive position of small business. ${ }^{1}$ The Technical Amendments Act of $1958^{2}$ accorded tax relief to closely held corporations. ${ }^{3}$ The Small Business Act of $1958^{4}$ extended permanent status to the Small Business Administration-hereafter referred to as SBA-and continued its prograin of loans and other assistance for sinall business. Finally, the Small Busimess Investment Act of $1958^{5}$ established what is hoped will be a more satisfactory means of meeting the needs of sinall business for equity capital and long-term credit than has existed previously. This comment analyzes the last named act.

\section{The institutional gap}

Congress has for some time been acutely aware of the difficulties facing small business concerns seeking adequate long term financing for moderization, grawth and development. ${ }^{6}$ It realized that commercial bauks are not able to furnish such long term financing, that public sale of small issues of securities involved prohibitive costs, and that private placements had afforded no general solution to the problem. ${ }^{7}$ This inability of sinall business to secure long term funds, often called an "institutional gap," 8 has been laid to a complex of nunerous interrelated

1104 Cong. Rec. 13392 (daily ed. July 23, 1958) ; S. KEP. No. 1652, 85th Cong., 2d Sess. 3 (1958) (hereinafter cited as SEN. CoMMrTTEE REPORT).

2 INT. REv. CODE OF $1954 \$ \$ 1371-77$, as added by the Technical Amendments Act of 1958, $\S 64,72$ Stat. 1650-57 (1958).

3 See Crane, Election of Certain Small Business Corporations as to Income Tax Status, 10 Hastings L.J. 271 (1959); Note, Optional Taxation of Closely Held Corporations Under the Technical Amendments Act of 1958, 72 Harv. L. Rev. 710 (1959); Anthoine, Federal Tax LegisLation of 1958: The Corporate Election and Collapsible Amendment, 58 CoLvM. L. Rev. 1146 (1958); CCH, TaX-Option Corporamions (1958); Meyer, Subchipter S Corporations, 36 TAXEs 919 (1958).

472 Stat. 690 (1958), 15 U.S.C.A. \& 633 (Supp. 1958). The SBA loan program is described in Federal Reserve Systems, Report on Financting Smatl Bustness, 85Th Cong., 2d Sess. 262-66 (Comm. Print 1958) (hereinafter cited as FEDERAI RESERVE REPORT), and in periodic SBA reports. Results of a survey of various operating aspects of the prograin are in Hearings on Legislation to Relieve Unemployment (Community Facilities, Area Redevelopment, and Small-Business Financing Bills) Before the House Committee on Banking and Currency, 85th Cong., 2d Sess. 776-78 (1958) (hereinafter cited as House Hearings).

572 Stat. 689 (1958), 15 U.S.C.A. §§ 661-696 (Supp. 1958) (bereinafter cited as SBI Act). Thirteen bills on the subject of sinall business financing, with widely varying provisions, were introduced in the 85th Congress: S. 719 (Sparkmau); S. 2160 (Sparkunaul); S. 2185 (Humphrey); S. 2286 (Fulbright); S. 3191 (Johnsol1); S. 3643 (Thye); S. 3651 (committee bill); H.R. 10345 (Patman); H.R. 10980 (Multer); H.R. 12026 (Hill); H.R. 12057 (Talle); H.R. 12064 (Patman); H.R. 12182 (Spence). S. 3651, introduced by Senators Johnson, Clark, Fulbright, Sparkman, Proxmire, Hill, O'Mahorrey, Humphrey, Beall, Case (N.J.), Payne and Stennis, was the bill which eventually became law.

${ }^{6}$ Sen. Committee Report 2; see Hearings on Credit Needs of Small Business Before a Subcommittee of the Senate Committee on Banking and Currency, Part $T$, 85th Cong, 1st Sess. (1957); Hearings on Financing Small Business Before a Subcommittee of the Serate Committec on Banking and Currency, 85th Cong., 2d Sess. (1958) (hereinafter cited as Senate Hearings); House Hearings, note 4 supra.

7 See 104 Cong. Rec. 9437 (daily ed. June 9, 1958).

${ }^{8}$ SEN. Committe REPORT 2. It is also sometimes referred to as the "Macmillan Gap," after the present Prime Minister of England who pointed out the same problem in regard to British Industry some years ago. Senate Hearings 54. 
causes. ${ }^{9}$ A study of small business financing conducted by the Federal Reserve System indicated that this gap could be filled at least in part by a federal program designed to stimulate the flow of private investment capital to small business concerns. ${ }^{10}$ It was apparent to Congress that the existing SBA loan program ${ }^{11}$ could not meet this need since its scope is severely limited. Moreover because the SBA program does not provide equity capital it does not contribute significantly to the long range growth and development of small businesses. ${ }^{12} \mathrm{~A}$ new and broader type of government program seemed necessary. Other countries had met a similar problem by developing special financial institutions to aid small businesses. ${ }^{13}$ Moreover, there existed ample domestic precedent for the creation of private financial institutions under federal auspices. ${ }^{14}$ Study of these experiences helped Congress formulate the new program embodied in the Small Business Investment Act of 1958. Privately owned small business investment companies-hereafter called SBI companies-are to be created, under supervision of a separate division in SBA, ${ }^{15}$ to carry out the purposes of the act: to supplement and stimulate existing private capital sources in filling the needs of small enterprises for equity capital and long term credit. $^{18}$

\section{ORGANization}

Under the act the following general requirements inust be met to organize an SBI company. It must be formed to carry out the purposes of the act.17 It must begin operations with at least $\$ 300,000$ paid-in capital and surplus, ${ }^{18}$ although half of this sum may sometimes be supplied by SBA. ${ }^{19}$ Finally, it must obtain a charter, ${ }^{20}$ and also be licensed by SBA. ${ }^{21}$

\section{The chartering process}

SBI companies will normally be incorporated under state law, ${ }^{22}$ but SBA may grant federal charters in particular states where it determines that state chartered

${ }^{9}$ Senate Hearings 55.

10 Federat Reserve Report 123; Senate Hearings 55.

1172 Stat. 698 (1958), 15 U.S.C.A. \$ 636 (Supp. 1958), originally enacted in 67 Stat. 232 (1953).

12 Federat Reserve Refort 123.

13 Sen. Concmattee Report 6. These countries include Canada, Great Britain, West Germany, France, Italy, Belgium, Sweden, and Norway.

14 Federal land banks, federal home-loan banks, banks for cooperatives, federal reserve banks, and federal intermediate credit banks all began with federal assistance, but with a view toward eventual private capitalization. The interest of the federal government in all these organizations either has been or will be terminated. $I d$. at 8 .

15 The Small Business Investment Division of SBA, established under SBI Act, \$201, 72 Stat. 690 (1958), 15 U.S.C.A. $\$ 671$ (Supp. 1958).

16 SBI Act, \& 102, 72 Stat. 689 (1958), 15 U.S.C.A. § 661 (Supp. 1958).

17 Ibid.; SBA Regulations, \& 107.308-7(a), 23 Fed. Reg. 9383, 9391 (Dec. 4, 1958) (heremafter cited as SBA Regs.). The new SBA regulations under the act require that any charter of an SBI company issued by a state contain the following provision: "This corporation is organized and chartered expressly for the purpose of operating under the Small Business Investment Act of 1958 and will operate in the manner and shall have the powers, responsibilities and be subject to the hmitations provided by said act and the regulations issued by the Small Business Administration thereunder." SBA Regs. \$ 107.301-1.

18 SBI Act, $\$ 302(\mathrm{a}), 72$ Stat. 692 (1958), 15 U.S.C.A. $\$ 682$ (a) (Supp. 1958). The anbiguities of this requirement are discussed in text following note 71 infra.

19 Ibid.

20 SBI Act, $\S 301$ (a), 72 Stat. 691 (1958), 15 U.S.C.A. § 681(a) (Supp. 1958).

21 SBI Act, $\$ 301$ (d), 72 Stat. 691 (1958), 15 U.S.C.A. \$ 681(b) (Supp. 1958).

22 See text following note 28 infra. 
companies could not operate in accordance with the purposes of the act. ${ }^{23}$ In chartering and in issuing licenses to state chartered companies, SBA is to consider among other things

\begin{abstract}
the need for the financing of small-business concerns in the area in which the proposed company is to commence business, the general character of the proposed managenent of the company, the number of companies previously organized in the United States, and the volume of their operations. ${ }^{24}$
\end{abstract}

The authority of SBA to issue federal charters expires on June 30,1961, because it was thought that any inhibiting state laws could be amended by that time. ${ }^{25}$

The question of the desirability of federal chartering was hotiy contested in Congress. The bill approved by the Senate would have granted SBA unlimited power to charter investment compamies until June 30, 1961, although state chartered SBI companies meeting the standards of the act could also have been licensed. ${ }^{26}$ The House amended the bill on the floor to exclude all possibility of federal charters. ${ }^{27}$ This opposition was bottomed upon several objections to federal incorporation. It was believed that federal chartering would not only be unnecessary, but that it would also encroach upon traditional powers of the states to grant corporate charters and would disrupt federal-state relations established by the Constitution. ${ }^{28}$ The bill which was finally adopted represents a compromise achieved in the Joint Conference Committee. The Senate provision for federal chartering was limited to situations in which SBA determined that state chartered companies would not be able to further the purposes of the legislation. ${ }^{29}$ It may well be that local statutes will nowhere prevent incorporation and operation of SBI companies under state law. ${ }^{30}$ Nevertheless, these companies are new and their function novel. Unforeseeable difficulties may yet prove the wisdom of retaining a limited provision for federal chartering. There is certainly ample precedent for the procedure. ${ }^{31}$

${ }^{23}$ SBI Act, $\$ 301$ (a), 72 Stat. 691 (1958), 15 U.S.C.A. § 681(a) (Supp. 1958).

24 SBI Act, $\$ 301$ (c), 72 Stat. 691 (1958), 15 U.S.C.A. $\$ 681$ (c) (Supp. 1958). Sponsors of the legislation did not desire great numbers of SBI companies to be formed and directed SBA to give close attention to the above mentioned criteria in issuing licenses. SEN. Commutrez REPORT 10.

$25 I d$. at 11. The expiration of the federal chartering power will not affect companies previously chartered by SBA.

28104 Cong. Rec. 9433 (daily ed. June 9, 1958).

27104 Cong. Rec. 13404-27 (daily ed. July 23, 1958) ; U.S. Code Cono. \& Adnnw. Newg 3911 (1958).

28 American Bar Association opposition to federal chartering impressed the nembers of the House. The ABA feared that federal chartering of corporations would raise insoluble questions as to whether federal or state law should govern their regulation, and that it would create a dangerous precedent for further encroacbment of federal authority in fields of law reserved to the states. Federal incorporation under the National Bank Act, I3 Stat. 101 (1864), 12 U.S.C. $\$ 24$ (1952), was distinguished as a special situation. Moreover, on the basis of a study conducted by the American Bar Foundation, it was claimed that every jurisdiction in the country was presently able to charter investinent companies which would be competent to perform the functions required by the act. Letter from Charles W. Steadmau to Hon. Charles W. Halleek, July 17, 1958, in 104 Cong. REc. 13404 (daily ed. July 23, 1958); Senate Hearings 407-09.

29104 Conc. Rec. 15160 (daily ed. Aug. 7, 1958).

30104 Cong. Rec. 13403-04 (daily ed. July 23, 1958).

31 The Federal Credit Union Act, 48 Stat. 1217 (1934), 12 U.S.C. $\$ 1754$ (1952); the National Banking Act, 13 Stat. 101 (1864), 12 U.S.C. \$ 24 (1952); and the act which permits federal chartering of Savings and Loan Associations, 48 Stat. 132 (1934), 12 U.S.C. § 1464 (1952). Furthernore, since federal funds will be involved and since SBA will proinulgate the rules and regulations for chartering, operation and supervision of both federal and state char- 
The act also contains a provision, operative until June 30,1961 , for converting state chartered investment and development companies into SBI companies. ${ }^{32}$ This opportunity should be welcomed by the state development coinpanies in particular. Especially active in New England, ${ }^{33}$ these organizations have been assisting the growth and developinent of small business concerns in the area of their operations, but their success has not been as great as expected because of restrictive lending policies $^{34}$ and lack of capital. ${ }^{35}$ The advantages of operation under the federal act should help to cure both defects.

\section{Initial capitalization and stock structure}

Before a small business investment company may begin operations, it must have paid-in capital and surplus of $\$ 300,000$, which will normally be obtained by issuing stock to private individuals or other entities, ${ }^{36}$ although if the full $\$ 300,000$ is not available from private sources, SBA, upon request of the incorporators, may agree to purchase debentures of the investment company in an amount equal to the deficiency if not more than $\$ 150,000 .{ }^{37}$ These debentures inay be subordinated to any other obligations of the company, as determined by SBA, and although technically debt, they are deemed part of paid-in capital and surplus for the purpose of meeting the initial capitalization requirement. ${ }^{38}$

The act itself does not preclude a complex stock structure. Althougl the proposed regulations insured adequate protection for senior securities, the final regulations fail to do so. ${ }^{39}$ However, applicable provisions of the Investment Company Act of 1940 require 200 per cent asset coverage for the preferred stock of closedend companies and proluibit issuance of senior securities by open-end compamies. ${ }^{40}$

tered companies, problems of the relation of federal and state law, discussed at various points hereafter, must inevitably arise. See 104 Conc. REc. 13417 (daily ed. July 23, 1958).

In some states, incorporation will require the approval of special authorities other than or in addition to whatever official normally grants corporate charters. E.g., in New York, the Superintendent of Banks will have to grant approval under N.Y. BANKING LAw §505.

32 SBI Act, $\S 401,72$ Stat. 696 (1958), 15 U.S.C.A. $\$ 691$ (Supp. 1958) ; SBA Regs. \$ 107.301-3(d).

33 State development corporations of one type or another have been active in: Conn., Me., Mass., Miss., N.C., N.H., N.Y., Pa., and R.I. They are authorized but not active in: Ark., Fla., Ga., Kan., Mich., Minn., S.D., Vt., and Wis. 104 Conc. Rec. 13399 (daily ed. July 23, 1958). 34 Id. at 13400.

35 Senate Hearings 373.

36 SEN. Conmurtee REPORT 11. See text at notes 71-78 infra as to the uncertain meaning of "paid-in capital and surplus."

37 SBI Act, $\$ 302,72$ Stat. 692 (1958), 15 U.S.C.A. $\$ 682$ (Supp. 1958). The unavailability of private funds will be deemed to exist if the incorporators submit a certificate to that effect. SBA Regs. $\$ 107.302-1$ (d). The debentures will bear interest at $5 \%$; maturities may not exceed 20 years. SBA Regs. $\$ 107.302-1$ (e).

38 SBA Regs. \$ $107.302-1(\mathrm{c})$.

30 The proposed regulations required that there "be provided for all classes of stock, to a measure acceptable to SBA, protection in the case of mismanagement, default, impairment of capital, omission of dividends, and other factors deemed appropriate by SBA. Proposed SBA Regulation 107.302-2(b), 23 Fed. Reg. 8356 (1958). The final regulations have also been weakened by deleting the proposed requirement that the aunount allocated to paid-in surplus may never exceed the amount allocated to capital stock. This means that in many states an SBI company may allocate large portions of contributed capital to a paid-in surplus account where it is available for dividends without regard to the rights of preferred shares. E.g., DEL. CoRP. LAW \$170. In Cahifornia, however, dividends may be declared from paid-in surplus only in favor of senior securities (those having a dividend preference) if there be such a class. Cax. CORP. CODE $\$ 1500$ (c).

40 Investment Company Act of 1940, $\$ 18$ (a), (f), 54 Stat. 817, 820 (1940), 15 U.S.C. $\S 80 a-18(a),(f)(1952)$. 
SBA regulations discourage promotional frauds by the requirement that shares may be issued only for cash or stock dividends and not for services, property or other non-cash consideration. ${ }^{41}$

\section{Stockholders and incorporators}

SBI companies may be organized and their shares owned by individuals, partnerships, corporations, insurance companies, or any other entities capable of investing in securities. ${ }^{42}$ Provision is also made for ownership of shares by national banks, by other member banks of the federal reserve system, and by non-member insured banks to the extent permitted under applicable state law. However, no bank may hold shares in an amount aggregating more than one percent of its capital and surplus, ${ }^{43}$ and some state chartered banks-those in California, ${ }^{44}$ for example-will not be able to purchase such shares at all.

Investment companies organized under a federal charter must have at least 10 incorporators, and the board of directors of such feclerally chartered companies must consist of nine members elected annually by the stockholders. ${ }^{45}$ State chartered investment companies inust conform to state law as regards the number and qualifications of incorporators and directors. ${ }^{46}$ In Cahfornia three or more persons may therefore organize a small business investment company, ${ }^{47}$ whose board of directors need have only three members unless an indefinite number is specified in the articles, in which case the minimum would be five. ${ }^{48}$ Since the purpose of requiring ten incorporators for federally chartered companies is to spread ownership and responsibility, ${ }^{49}$ however, it would seen that in approving state chartered compamies SBA should give preference to those which most nearly meet the organizational requirements imposed upon federally chartered companies. ${ }^{50}$

In line with the apparent congressional desire that ownership of these companies be widely spread, SBA regulations provide that where several companies have substantially the same beneficial ownership, the capital of only one of them will be supplemented by SBA. ${ }^{51}$ Probably the greatest inhibition against concentrated ownership in SBI companies is the harsh tax rule relating to personal holding companies. If more than 50 per cent of the outstanding stock of a corporation is owned directly or indirectly by five or fewer persons, and at least 80 per cent of the company's gross income for any taxable year is personal bolding company income, then such income must be fully distributed or extremely heavy penalty taxes are imposed in addition to the normal corporate tax and surtax. ${ }^{52}$ Personal holding company income includes dividends, mterest, and gains from the sale of

41 SBA Regs. $\$ 107.302-2$. But an exception is made for organizational expenses approved by SBA. SBA Regs. $\$ 107.201-5$ (c).

42 SEN. ConMMITte REPORT 11.

43 SBI Act, $\$ 302$ (b), 72 Stat. 692 (1958), 15 U.S.C.A. $\$ 682$ (b) (Supp. 1958).

44 See CAL. FIN. CODE $\$ 761$, restricting bank purchases, acquisitions and holdings of corporate stock.

${ }^{45}$ SBI Act, § 301, 72 Stat. 691 (1958), 15 U.S.C.A. § 681 (Supp. 1958); SBA Regs. § 107.301-3.

46 SBA Regs. § 107.301-3.

47 CAL. CoRp. CODE $\$ 300$. Persons includes corporations as well as natural persons. Cax. CORP. CODE $\$ 18$.

48 CAL. Corp. CODE $\S 301$ (d).

49104 Cong. REc. 13412 (daily ed. July 23, 1958).

60 See U.S. Code Cong. \& AdMTN. News 3911 (1958).

E1 SBA Regs. \$ 107.302-1(f).

52 INT. REv. Code of 1954, §§ 541-45; Rev. Rul. 59-69, Mar. 9, 1959. 
securities ${ }^{53}$ - the very types of income SBI companies will earn. Where there are ten or fewer shareholders, personal holding company status follows automatically. This may be a trap for closely held SBI companies.

\section{Financing}

The adequacy of the machinery that Congress established to meet the financial needs of small business concerns depends in the last analysis on whether private investors can be persuaded to provide whatever capital the SBI companies are capable of utilizing. ${ }^{54}$ For this reason a consideration of the sources of funds available to these companies is appropriate.

\section{A. Loans to SBI Companies}

In addition to contributing up to $\$ 150,000$ to the basic capital of SBI companies through purchase of subordinated debentures, SBA is authorized to provide further funds by purchasing other obligations of these companies up to an amount not exceeding fifty per cent of their "paid-in capital and surplus." 55 Regulations provide that SBA will lend money only if the licensee is unable to borrow or otherwise secure operating funds from private sources. ${ }^{56}$ This limitation, while not required by the act itself, is in harmony with the statement of policy in the act and also with the expressed intention of its proponents that public funds should not be used where private capital is available. ${ }^{.57}$

SBI companies also have authority to engage in private borrowing. ${ }^{58}$ Proposed regulations provide only that the ratio of debt to "paid-in capital and surplus" shall not exceed four to one without prior consent of $\mathrm{SBA}^{58}$ and that the proposal for initial licensing of an SBI company under the act disclose plans as to prospective borrowing by the proposed licensee. ${ }^{60}$

53 INT. REv. CODE OF 1954, § 543(a).

54 The initial public reaction to the new program is described in $\mathrm{CCH}$, SMaLr Business INVESTAIENT ACT WITH EXPLANATION 7 (1958).

65 SBI Act, § 303(b), 72 Stat. 693 (1958), 15 U.S.C.A. \&683(b) (Supp. 1958). Section 302 (a) subordinated debentures are expressly made part of "paid-in capital and surplus" for this purpose.

Because of the new legislation, SBA now has three major programs for supplying funds directly and indirectly to small business: (1) It may make direct loans to small businesses under the Small Business Act (see note 4 supra). (2) Under the new legislation, it may finance SBI companies, first, by contributing to the basic capital of sucl companies througl purchase of subordinated debentures (see text at notes 37-38 supra), and second, by lending additional funds under $\S 303(\mathrm{~b})$, discussed above. (3) In addition, $\S \S 501-02$ (15 U.S.C.A. $\$ \S 695-96$ (Supp. 1958)) of the new legislation establish a progran of lending to state and local development companies.

56 SBA Regs. 107.303-2(a). Further provisions, under $\$ \S 107.303-2(\mathrm{~b}),(\mathrm{c})$, are similar to those stated in note 37 supra.

57 SBI Act, § 102, 72 Stat. 689 (1958), 15 U.S.C.A. \$ 661 (Supp. 1958); SEN. ConarrTreE Report 12; Senate Select Contartiee on SMatr Business, Smatr Bustness Investatent Act Texr and Explanatron, 85th Cong., 2d Sess. 17 (Comm. Print 1958) (hereinafter cited as Sen. Select Comantiee Prnst). Regulations indicate further that the loans are to be made for two purposes: for regular operations of the borrower, and to render it unnecessary for licensees to maintain substantial aniounts of idle cash to protect outside investınents and loans. SBA Regs. $\$ 107.303-3$.

${ }_{68}$ SBI Act, $\$ 303($ a), 72 Stat. 692 (1958), 15 U.S.C.A. $\$ 683$ (a) (Supp. 1958).

59 SBA Regs. \$ 107.303-1(a).

${ }^{60}$ SBA Regs. \& 107.303-1(b). 


\section{Regulation of debt to capital ratio}

The problem of investment company indebtedness is somewhat complicated. Its importance lies in the "leverage" exerted on common stock by outstanding debt or senior capital; that is, senior securities magnify the effect of fluctuations in the value of portfolio securities on the value of common shares. The higher the debtcapital ratio, the more speculative is the common stock. For this reason, the Investment Company Act of 1940 restricts the amount of permissible investment company indebtedness and senior capital. ${ }^{61}$

The small business investments of an SBI company may prove to be intrinsically more speculative than the portfolio securilies of most regulated investment companies. ${ }^{2}$ Therefore, the dangers from excessive leverage are accentuated in the SBI company. Yet the only provisions of the 1940 act from which Congress saw fit to exempt SBI companies are the debt limitations. Apparently, the authors of the new legislation felt that SBI company securities had to be highly speculative to attract private capital into the institutional gap. ${ }^{.3}$

The ratio of total outstanding indebtedness of SBI companies to "paid-in capital and surplus" 04 may be as high as $4: 1{ }^{65}$ and regulations indicate that SBA may, in individual cases, relax even this limitation. ${ }^{00}$ The ratio is established by SBA rather than by the act itself-Congress concluded that the experimental nature of the program called for greater flexibility than would exist if a ratio were frozen into the statute. ${ }^{67}$ The $4: 1$ limitation is a radical departure from the otherwise applicable Investment Company Act of 1940, which himits investment company debt to approximately one-half net worth. ${ }^{68}$ The Senate Committee on Banking and Currency thought this ratio too restrictive for its present purposes, so it provided an automatic exemption from the 1940 act limitation for closed-end SBI companies, ${ }^{69}$ in spite of SEC opposition to any relaxation of the securities

61 Investment Company Act of $1940, \S 18,54$ Stat. 817 (1940), 15 U.S.C. $\$ 80 a-18$ (1952).

62 Sponsors of the act evidently recognized this (see Sen. Comarrtien Rerort 12), as did the SEC (see Senate Hearings 241) and other witnesses at the hearings (e.g., Senate Hearings 54). See also text at notes 208-12 infra.

Registered investment companies are required to file statements of investment policy with the SEC, by $\$ 8$ of the Investment Company Act of 1940, 54 Stat. 803 (1940), 15 U.S.C. § 80a-8 (1952), and may not change such policies except in compliance with §13, 54 Stat. 811 (1940), 15 U.S.C. \& 80a-13 (1952).

63 See Sen. Commitrtee Report 12 ; Senate Hearings 54; Sha. Select Commitree Print 17. 64 "Paid-in capital and surplus" includes any $\S 302(\mathrm{a})$ debentures of the SBI company held by SBA. SBA Regs. § 107.303-1 (a).

65 Ibid.

66 Ibid.

67 SEN. COMAMITTEE REPORT 13.

68 Investment Company Act of $1940, \S 18,54$ Stat. 817 (19.40), 15 U.S.C. $\$ 80 \mathrm{a}-18$ (1952). Actually, the test is phrased in terms of the ratio of assets to debt-not more than $3: 1$. While the same ratio is used in the hmitation imposed on both open and closed-end companics, in the case of open-end companies more restrictions are placed on the nature of permissible debtit is limited to bank loans-and the ratio limitation continues applicable at all times after the financing has been completed. Compare subsections (a) and $(\mathrm{f})$ in $\S 18$ of the Investment Company Act of 1940, 54 Stat. 817 (1940), 15 U.S.C. \& 80a-18 (1952).

69 The 1:2 limitation on open-end company debt, contained in $\$ 18(\mathrm{f})$ of the $1940 \mathrm{act}$, is still applicable to any SBI company so organized; $\S 307$ (c) of the new act, 72 Stat. 694 (1958), 15 U.S.C.A. § 80a-18(k) (Supp. 1958), exempts SBI companies only from the limitation applying to closed-end companies. Whether organization of SBI companies on an open-end basis should be permitted is discussed in text following note 84 infra. 
laws. ${ }^{70}$ There is no limit on the amount of private capital which may be borrowed by an SBI company provided the $4: 1$ ratio is not exceeded. ${ }^{71}$

The difficulty with the SBA regulation lies in the uncertain meaning of the term "paid-in capital and surplus," used in the test of permissible indebtedness. It is not clear why, in relaxing the numerical ratio, SBA departed from the 1940 act test in phrasing its own. The problem that arises from the SBA test is whether the words paid-in modify surplus as well as capital, or whether earned surplus and capital surplus transferred from earnings may be included in the computation.

Paid-in capital and surplus is not among the phrases defined by the act or regulations. ${ }^{72}$ The phrase appears in the act, however, in the minimum capital requirement of section 302 (a). Presumably, SBA meant it to have the same ineaning in its regulation as it has in section 302 (a). But its meaning in the latter section is open to the same question-are retained earnings and other forms of nonpaid-in surplus ${ }^{73}$ included? The question may not be important under section 302 (a) with respect to a company about to be initially organized for operation under the act, for any surplus of such a company inust of necessity be paid im. But a converted development company may have earned surplus, and there is no sound reason why such surplus should not be counted toward the minimum $\$ 300,000$. $^{\mathbf{7 4}}$

If retained earnings are included in surplus, as used in the regulation, SBI companies should avoid borrowing the full amounts permissible, to protect agaimst increased ratios resulting from future operating deficits carried to surplus. On the other hand, if surplus in the computation inust be paid in, it is a relatively fixed amount-except to the extent state law permits dividends to be paid from it-and SBI companies might safely borrow up to the himit of the regulation.

A further problem arises under the SBA test. The two factors in the ratio are not subject to fluctuation with fluctuations in the value of portfolio securities. For this reason, the limitation may in some cases be unreahistic in terms of the value of assets available to be applied agamst debt. The test in the Investment Company Act of 1940, phrased in terms of "asset coverage," reflects a sounder view of the nature of investment companies and corporate finance in general. Indebtedness must "have an asset coverage of at least" a specified minimum percentage- $-300 .{ }^{75}$ Asset coverage is defined as the ratio which the market value $e^{76}$ of the total assets of the investment company, less an allowance for liabilities deemed irrelevent to

70 Senate Hearings 239. SBA, on the other hand, favored an automatic exemption from both the Securities Act of 1933 and the Investment Company Act of 1940. Senate Hearings 114; House Hearings 992-93.

71 Applicants under the program must, however, detail their plans and policies in regard to borrowing from private sources. SBA Regs. $\S 107.303-1$ (b).

72 Definitions are in SBI Act, § 103, 72 Stat. 690 (1958), 15 U.S.C.A. § 662 (Supp. 1958); SBA Regs. § 107.103-1.

73 E.g., earned surplus transferred to stated capital, as under CaL. CORP. CODE $\$ 1903$.

${ }^{74}$ Although earned surplus is available for dividends, so is paid-m surplus in most states (e.g., CaL. CORp. CODE $\$ 1500$ (c) ; DeL. CORP. LAW $\$ 170$ ), and a paid-in surplus is permissible under the act. SBI Act, § 302 (a), 72 Stat. 692 (1958), 15 U.S.C.A. \$ 682 (a) (Supp. 1958). Therefore, nothing in the act or regulations explicitly prevents paying out as dividends any or all of a paid-in surplus invested in a licensee only for purpose of meeting the $\$ 300,000$ mitial capitalization requirement. Yet, because of the possibility of repurchases of open-end shares leaving a company with capital below $\$ 300,000$, SBA has indicated that it will not license open-end companies. See note 84 infra.

${ }^{75}$ Investment Company Act of 1940, $\$ 18(a)(1)(A), 54$ Stat. 817 (1940), 15 U.S.C. \$ 80a-18(a) (1)(A); see also § $18(f)(1)$.

76 Defined in Investment Company Act of 1940, § 18(b), 54 Stat. 818 (1940), 15 U.S.C. \$ 80a-18(b). 
the computation, bears to the aggregate amount of the indebtedness to be linited. ${ }^{77}$ In other words, the provision for controlling indebtedness in the 1940 act uses a ratio of assets to debt, both of which are realistically valued, rather than a ratio of debt to the elusive capital-surplus complex. The test under the 1940 act has two advantages over the new one. It is workable, having a somewhat more definite meaning, and it is realistic in that it bears a close relation to the ability of the investment company to meet its obligations as they mature. ${ }^{78}$

The debt-capital ratio may also raise problems under state Blue Sky laws, since most SBI companies will be state chartered and will therefore be subject to state regulation of the sale of their securities. Regulations of the California Corporation Commissioner as to debt securities are an instructive example. Secured obligations of new and mactive companies must be supported by "adequate junior financing,",70 and unsecured obligations of such companies will ordinarily be considered with disfavor if the issue creates indebtedness in excess of two times the tangible net worth of the issuer. ${ }^{80}$ For going concerns, average annual earnings after taxes for the preceding five years and earnings for the preceding year must ordinarily be at least two times the annual interest requirements of either secured or unsecured issues. $^{81}$ Of course, if the contemplated obligations are to be issued to investors who understand the nature of their purchase, restricted permits may be made available for the transaction. ${ }^{82}$ It is too early to know what position the Commissioner will take as to public distribution of SBI company debt securities. Assuming that he does not relax existing criteria as to the permissible debt-capital ratio, it seems that in California SBI companies will not be permitted in all cases to take advantage of the $4: 1$ ratio permitted by SBA, at least through a public offering of debt securities.

\section{B. Equity Capital}

Another source of SBI company funds, equity capital, ${ }^{83}$ miglit theoretically be obtained under an open-end form of organization by the continuous sale of shares

77 Investment Company Act of $1940, \S 18(\mathrm{~h}), 54$ Stat. 820 (1940), 15 U.S.C. $\S 80 a-18(\mathrm{~h})$.

78 One differentiating factor, actually pertinent only to the question of what resulting ratio seems proper rather than to the type of test used, is that the 1940 act limitation is designed to protect against excessive leverage. Under the new act, leverage is to be encouraged, since it is the speculative quality of the investment that Congress expect; to attract private capital. See note 63 supra. The 4:1 ratio, which permits extreme leverage, should accomplish that objective.

7910 Car. AdMotr. CODE $\$ 466$.

8010 CaL. ADMATN. CODE $\$ 480$.

81 10 CaL. ADMTN. CODE $\$ \S 475,486$.

82 CaL. CORP. CODE $\$ \$ 25507-08$. For a general discussion of the California Corporation Commissioner's powers to condition permits to issue securities so that transactions will be fair, just, and equitable to those who may be affected by them, see Jennings, The Role of the States in Corporate Regulation and Investor Protection, 23 LAW \& ConTEMP. PROB. 193, 214-16 (1958).

83 SBA requires that each hicensee maintain at all times an "unimpaired capital." Impairment exists when the earned surplus deficit exceeds either the paid-in surplus or $50 \%$ of combined capital stock and paid-in surplus, with assets and liabilities valued by sound accounting and investment principles. SBA Regs. \$ 107.308-1. The penalties for permitting an impairment of capital are that SBA may withhold any further financial assistance and may obtain judicial cancellation of the company's bicense. SBA Regs. \$\$ 107.308-2(b), 308-11. To avoid these risks, SBI companies should allocate a sufficient portion of capital to paid-in surplus so that an annual operating deficit, before an earned surplus has been accunulated, will not result in capital impairment, as defined. See text at notes 107 infra and following, as to difficulties with respect to accumulating earned surplus.

It should further be noted that the $\$ 300,000$ minimum capital requirement has no apparent selation to this requirement that licensees maintain capital unimpaired at all times. 
in the SBI company-carrying with it however the continuing right of each shareholder to have the company repurchase such shares at his option; under a closedend form of organization by successive issues of stock as the need for additional funds arises; and under either form of organization by the retention of earnings. Difficulties with the first and last of these methods arise, however.

\section{Open-end companies}

SBA evidently will not license open-end organizations to operate under the act. ${ }^{84}$ The reason given - that the repurchase feature of open-end shares is inconsistent with the $\$ 300,000$ capital requirement ${ }^{85}$-seems weak. But the decision is probably wise, although open to argument.

In the course of the Senate committee hearings, some testimony indicated that closed-end companies would be the appropriate vehicle for the program contemplated by Congress. ${ }^{88}$ Nothing in the final act or regulations necessarily limits SBI companies to the closed-end form, however. ${ }^{87}$ There are four objections to open-end organizations which must nevertheless be considered.

First, the exemption from the debt limitation of the Investment Company Act of 1940 is available only to closed-end companies. ${ }^{88}$ Thus, unless an open-end company were not subject to regulation under the act, ${ }^{89}$ it could not issue senior securities of any kind, and could borrow money only from banks, maintaining at all times 300 percent asset coverage of such borrowings. ${ }^{90}$ Arguably, an imperfectly expressed congressional intent that only closed-end companies be licensed under the new act miglit be seen in the failure of Congress to exempt SBI companies from the 1940 act limitation on open-end company debt.

Another difficulty with open-end organization arising from the terms of the act itself is the provision that "each company authorized to operate under this act shall have a paid-in capital and surplus equal to at least $\$ 300,000 . " 101$ This pro-

84 Letter from Albert C. Kelly, Acting Deputy Administrator, Investment Division, SBA, to authors, Dec. 22, 1958. Pertinent portions of the letter read: "[W] hile there is no provision of the Sinall Business Investınent Act of 1958 which directly prohibits licensing an open-end investment company to operate thereunder, the inherent distinguishing charactersitic of openend companies (redeemability of capital stock at the option of the holders) would bar licensing such counpanies by reason of the statutory minimum capital and surplus requirements." (Emphasis added.)

85 Ibid.

80 Senate Hearings 330.

87 SBA is authorized on specified conditions to license "any investment company" initially organized under state law expressly for the purpose of operating under the act and is not limited to licensing closed-end companies. See SBI Act, $\S 309$, 72 Stat. 696 (1958), 15 U.S.C.A. $\$ 688$ (Supp. 1958). (Emphasis added.) Similarly, the legisiation permits conversion of "any investment company" to an SBI company. See SBI Act, § 401, 72 Stat. 696 (1958), 15 U.S.C.A. § 691 (Supp.1958). (Einphasis added.) Nor is there any suggestion in the proposed SBA regulations that an open-end company may not qualify for licensing as an SBI company.

$88 \S 307$ (c) of the new act, 72 Stat. 694 (1958), 15 U.S.C.A. $\$ 80 a-18(k)$ (Supp. 1958), exempts companies from $\$ 18$ (a) (1) (A) of the Investment Company Act of 1940, 54 Stat. 817 $(1940), 15$ U.S.C. $\$ 80 a-18(a)(1)(A)$ (1952), applicable to indebtedness of closed-end companies, but not from $\$ 18(\mathrm{f})$, which limits debt of open-end organizations.

80 Companies exempt from 1940 act requirements are discussed in text at notes 112 infra and following.

80 Investment Company Act of 1940, $\$ 18(f)(1), 54$ Stat. 820 (1940), 15 U.S.C. $\$ 802-$ 18(f) (1) (1952).

01 SBI Act, § 302(a), 72 Stat. 692 (1958), 15 U.S.C.A. \$ 682 (a) (Supp. 1958). 
vision is cited by SBA to support its refusal to license open-end companies. ${ }^{92}$ If an SBI company were initially capitalized at the specified amount, and were also permitted to repurchase its shares whenever its stockholders so requested, this capital limitation could be circumvented. But in states where dividends may be paid from paid-in surplus, the limitation can equally be ayoided by the dividend device.93 The regulations suggest that SBA has not sufficiently concerned itself with the problem, for they merely restate the $\$ 300,000$ requirement "as a condition to the issuance of a License," ${ }^{24}$ rather than as a continuing condition to operation under the act, although the statutory language itself is susceptible to either construction. SBA should make its position clearer.

The third and most serious objection to licensmg open-end companies under the act concerns the relation of the distinguishing characteristic of an open-end organization-the continuous sale and repurchase feature-to the nature of the financial operations of SBI companies. The purpose of an SBI company is to supply long term capital to small business concerns, through purchase of convertible, callable debentures ${ }^{95}$ and through long tern loans. ${ }^{96}$ Because SBI company portfolios will probably lack liquidity, there being no ready resale market for the long term paper of small businesses, excessive demands on the SBI companies to repurchase their own securities could force sales of portfolio securities at disastrously low prices having no relation to underlying value, and could also force sale of long term paper at unreasonable discounts. It is this lack of a liquid portfolio that will distinguish SBI companies froin the typical regulated investment company.

This problem cannot be met by protective provisions in the debenture and loan arrangements of the investment company. To allow the SBI company to require, as a term of the small busmess debentures purchased by it, a provision for retirement by the small business at the option of the holder of the debenture is unfeasible, even though the act and the regulations are silent on maturities. In the first place, if the debentures have already been converted into common shares in the small business, redemption at the shareholder's option raises legal difficulties under some state corporation laws. ${ }^{97}$ Even when legal, and even when the debentures are unconverted, such a requirement would make this type of financing a precarious basis for small business growth, expansion or modernization, and therefore would be inconsistent with the purposes of the act. ${ }^{98}$ While the regulations do not prohibit such a requirement, the terms of the debentures are subject to prior SBA approval, ${ }^{99}$ which SBA could not reasonably grant. Also, since maturities of long term loans are himited by the act-twenty year maxinum, ${ }^{100}$ and by the regulations-five year minimum, ${ }^{101}$ provision for earlier retirement at the election of the

92 See note 84 supra, and accompanying text.

93 See note 74 supra.

94 SBA Regs. \$§ 107.302-1(a), 201-5(c).

05 SBI Act, $\$ 304,72$ Stat. 693 (1958), 15 U.S.C.A. \$ 684 (Supp. 1958).

96 SBI Act, $\$ 305,72$ Stat. 693 (1958), 15 U.S.C.A. $\$ 685$ (Supp. 1958).

${ }^{97}$ E.g., CAL. CoRP. CoDE $\$ 1101$, which provides that any right of redemption must be exerciseable solely by the corporation issuing the redeemable shares. On redemption and repurchase of shares generally, see Dodd, Purchase and Redemption by a Corporation of Its Own Shares: The Substantive Law, 89 U. Pa. L. Rev. 697 (1941); Balinstinge \& SterLIng, Califoraia CORPORATION LAW 201 (1949).

08 See SBI Act, $\$ 102,72$ Stat. 689 (1958), 15 U.S.C.A. $\$ 661$ (Supp. 1958).

${ }^{90}$ SBI Act, $\$ 304$ (b) (1), 72 Stat. 693 (1958), 15 U.S.C.A. $\$ 684$ (b) (1) (Supp. 1958) ; SBA Regs. $\S 107.304-1$ (i).

100 SBI Act, § 305(d), 72 Stat. 694 (1958), 15 U.S.C.A. § 685(d) (Supp. 1958).

101 SBA Regs. $\$ 107.305-1$ (b). Shorter loans for the protection of existing long term loans are, however, permissible. Ibid. 
creditor SBI company seems clearly out of the question. Objections to long term financing on this unstable basis are similar to those mentioned with respect to debentures.

To avoid forced liquidation of an open-end SBI company portfolio at unreasonably low prices, it would be necessary to condition the repurchase features of the open-end shares. But this would raise an almost insoluble problem. The Investment Company Act of 1940 prohibits postponement by registered investment companies "of payment or satisfaction upon redemption of any redeemable security in accordance with its terms for more than seven days after tender of such security to the company," 102 except in certain circumstances not here pertinent. Providing in the instrument that "redemption" does not occur until an appropriate time-within seven days of which the company will be able to pay the redeeming shareholder-does not seem sufficient to comply with the section, since payment must also be within seven days after tender..$^{103}$

The fourth problem arises from the difficulty of valuing portfolio investments daily for the purpose of determining selling and repurchase prices of open-end company shares. Normally, these prices are based on market value of the company's portfolio. ${ }^{104}$ Obviously, where there is no market for most of the portfolio, as will probably be the case with the SBI companies, some other basis must be used. Values based on cost or on other criteria involve an element of unreality, and prices calculated on such bases raise problems of dilution of existing shareholders' investments or, on the other hand, unfairness to the purchaser. In California, the Corporation Commissioner would do well to subject any such provision to close scrutiny, where sale of shares to the public is contemplated. ${ }^{105}$

For these reasons, the determination by SBA that open-end organizations shall not be licensed as SBI companies appears wise, although the total silence of the regulations on the problem is unfortunate. ${ }^{108}$

\section{Retained earnings}

Although it was the congressional purpose to make available a larger quantity of private capital for small business enterprises, Congress did not deem it advisable to encourage retention of SBI company earnings for this purpose by providing relief from the special taxes on accumulations of earnings and on personal holding

102 Investment Company Act of 1940, \$22(e), 54 Stat. 824 (1940), 15 U.S.C. \$ 80a-22(e) (1952). (Emphasis added.)

103 Of course, if the SBI company comes within one of the exceptions to the act, the requirement will not apply. See text following note 113 infra.

104 See Investment Company Act of 1940, § 22a, 54 Stat. 823 (1940), 15 U.S.C. § 80a-22 (1952), and rules of the National Association of Investment Dealers thereunder, Rules of Fair Practice, Rule 26, Nat'l Ass'n of Securities Dealers Inc., 9 SEC 38 (1941) ; also, 10 Car. Admon. CODE $\$ 561$, providing for valuation of portfolio securities on a basis fair and just to shareholders, in the absence of a market.

105 See 10 CAL. ADMINN. CODE $\$ 561$ and note 104 supra.

106 Further objections to open-end organization would arise in some states because of restrictions on activities which are part of the financial program Congress desired SBI companies to conduct. For instance, 10 CAL. ADMrrv. CODE $\$ 560$ flatly prohibits the making of loans by open-end investment companies-the Investment Company Act of 1940, 21 , prohibits loans to unrelated persons only if the investment policies of the company recited in its registration statement do not permit them. 54 Stat. 822 (1940), 15 U.S.C. \& 80a-21 (1952). Because the loan provisions of $\S 305$ of the SBI Act are an essential part of the new program, the prohibition of lending by open-end investment companies selling shares in California would in itself create a defect in the powers of a company sufficient to justify SBA in refusing to license SBI companies in California. 
companies. ${ }^{107}$ Because of these taxes, retained earnings will play a limited role in the growth of SBI companies. ${ }^{108}$

The personal holding company tax has been considered above. Retained earnings of SBI companies not subject to taxation as personal holding companies, in excess of $\$ 100,000$ annually, ${ }^{109}$ will be subject to the accumulated earnings tax imposed by Internal Revenue Code section 531. Apparently the companies may not avoid the additional tax by showing that earnings are retained for the "reasonable needs of the business" and not to avoid taxation of the shareholders, ${ }^{110}$ since they are investment companies. ${ }^{111}$ To avoid these taxes, SBI companies subject to the personal holding company provisions because of concentrated ownership must distribute all "personal holding company income"-that is, substantially all income -and other SBI companies are limited to retention of $\$ 100,000$, annually.

To encourage shareholders to leave earnings with the company, an SBI company might adopt the procedure of many ordinary investment companies which offer shareholders the option of receiving distributions in additional shares of the company's stock, but shareholders so electing will nonetheless be subject to taxation as though they had elected to receive the distribution in cash.

\section{Exemptions from the Securities Acts}

\section{Investment Company Act of 1940}

With the one exception already noted regarding the debt-capital ratio, the Investment Company Act of 1940 applies to SBI companies in the same way that it does to other investment companies. This act, administered by the SEC, generally subjects investment companies with publicly held shares to regulation. Impor-

107 INT. REv. CODE OF $1954 \$ \$ 531-37$ (corporations improperly accumulating surplus) and \$§ 541-47; Rev. Rul. 59-69, Mar. 9, 1959 (personal holding companies).

108 The record permits opposing inferences as to Congress' intention respecting accumulation of earnings. Two of the earlier small business investment bills proposed in the Senate, S. 2160, 85th Cong., 2d Sess., and S. 3191, 85th Cong., 2d Sess., contained tax measures designed to encourage substantial accumulations of earnings as part of a general scheme of taxation based on the present tax treatment of regulated investment comparies. Companies organized under these two bills would have been taxed - or rather would have been permitted to avoid all income taxes-as regulated investment companies without being required to distribute earnings as must the regulated companies. See text following note 198 infra. Instead, the new investment companies would have been permitted to build up a reserve equal to the lesser of (1) $50 \%$ of invested capital or (2) accumulated earnings and profits. S.2160, \& 109(d); S.3191, \&417(e). These features were opposed by the Treasury: "The proposed special tax treatment is based on a complex extension and liberalization of the 'conduit' or 'pass-through' treatment under the regulated investment company provisions. However, simce the proposed investinent companies ... would be exempt not only on their distributions to [shareholders] but also on amounts of retained earnings put into a tax-exempt reserve, they would be substantially tax exempt even where they did not in fact pass their income on to shareholders. This would be inconsistent with the conduit principle on which the regulated investment company provisions are based .... The adoption of the proposed tax-free reserve treatment ... would constitute an undesirable precedent for similar treatment elsewhere." Senate Hearings 169-70 (statement by Dan Throop Smith, Deputy to the Secretary of the Treasury). The proposed tax-frec reserve features of the two bills were not included in the program enacted into law. Tax features of that prograin were severed from S. 3651, the conimittee draft bill finally approved by the Committec on Banking and Currency; instead they became $\S 57$ of the Technical Amendments Act of 1958, discussed at various points herein.

109 INT. REv. CODE OF 1954 § 535(c) (3).

110 Ordinary business corporations are permitted to make such a showing under INT. REv. CODE OF 1954 \$ 532-33.

111 Int. Rev. CoDE of $1954 \S 535$ (c) (3). 
tant in this regard are provisions requiring reports of beneficial ownership of, and transactions in, the securities of registered closed-end investment companies, which must be filed with the SEC by officers, directors, investment advisers, and 10 percent shareholders. ${ }^{112}$ Important also is the provision requiring that an initial $\$ 100,000$ net worth be raised privately or from not more than 25 persons before a public offering of the mvestment company securities may be made. ${ }^{113}$ There are, however, certain issuers of securities which are not deemed "investment companies" withm the meaning of the act. Of particular interest to small busmess investment companies is the provision in section 3 which excludes from the definition of "investment company," for purposes of regulation under the act, any issuer the securities of which are beneficially owned by not nore than 100 persons and which is not making or does not presently propose to make a public offering of its securities. ${ }^{114}$ In determining whether an offering is public or private the same criteria govern as do under the Securities Act of $1933 .{ }^{115}$ Assuming a public offering, the investment company unust file a registration statement under the Investment Company Act of $1940^{116}$ and, unless exempt, also under the Securities Act of 1933.117 In the interest of simplification the SEC has adopted a form that enables an SBI company to register under both acts at once. ${ }^{118}$ Even if the public offering is entirely intra-state, the registration requirements of the Securities Act of 1933 must be complied with; the intra-state exemption from the $1933 \mathrm{act}^{119}$ is made mapplicable to any security of a registered investment company by the provisions of the Investment Company Act of 1940.120

During the Senate debate, Senator Thye, who introduced an Administration bill which was not adopted, ${ }^{121}$ urged a general exemption for SBI companies from the Investment Company Act. It was his feeling that these companies would exercise functions more like banks than those of ordinary investment companies. ${ }^{122}$ However, a general exemption was not granted by Congress because it was impressed with the SEC's view that investors in these companies are no less in need

112 Investment Company Act of 1940, $\$ 30$ (f), 54 Stat. 837 (1940), 15 U.S.C. $\$ 80 a-29$ (f) (1952). Such persons are subject to the same duties and liabilities as are imposed by $\S 16$ of the Securities Exchange Act of 1934, 48 Stat. 896 (1934), 15 U.S.C. \$ 78p (1952).

113 Investment Company Act of 1940, \& 14, 54 Stat. 812 (1940), 15 U.S.C. $\S 80 a-14$ (1952).

114 Investment Company Act of 1940, $33(\mathrm{c})(1), 54$ Stat. 798 (1940), 15 U.S.C. \& 80a3 (c) (1) (1952). For the purposes of computing the maximum number of investors, all the security liolders of any company owning $10 \%$ or more of the voting stock of the investment company must be included. Investment Company Act of 1940, § 3(c) (1), 54 Stat. 798 (1940), 15 U.S.C. $\$ 80 \mathrm{a}-3$ (c) (1) (1952).

115 See Senate Hearings 237. As to what constitutes a public offering, see In re Tle CrowellCollier Publishing Co., Securities Act Release No. 3825 (Aug. 12, 1957) ; SEC v. Ralston Purina Co., 346 U.S. 119 (1953), noted 4 CATHolrc U.L. Rev. 70 (1954); 21 FordHaM L. Rev. 183 (1952) ; 66 HaRV. L. Rev. 1144 (1953) ; 39 VA. L. ReV. 376 (1953); see also Loss, SecurItmes RegULATION 394-403 (1951).

116 Investment Company Act of $1940, \S 8,54$ Stat. 803 (1940), 15 U.S.C. § 80a-8 (1952). 117 Securities Act of 1933, § 6, 48 Stat. 78 (1933), 15 U.S.C. $\$ 77 f$ (1952).

118 CCH Fed. Securities L. REp. \7 79,629.

119 Securities Act of 1933, $\$ 202,48$ Stat. 906 (1933), 15 U.S.C. $\S 77 c(11)$ (1952).

120 Investment Company Act of 1940, § 24(d), 54 Stat. 826 (1940), 15 U.S.C. § 80a-24(d) (1952).

121 S. 3643, 85th Cong., 2d Sess. (1958) (see Senate Hearings 26).

122104 Conc. REC. 6032 (daily ed. April 21, 1958). In this Senator Tlye was supported by SBA (Senate Hearings 114-15; House Hearings 992-93), and opposed by the SEC (Senate Hearings 239). His conception of the companies as banks, for purposes of securities regulation, seems unsupportable in view of the possibilities of extreme leverage in the common stock and the speculative character of the underlying portfolio. See text at notes 61-71 supra, 208-12 infra. 
of protection than other investors generally. ${ }^{123}$ This seems sensible, especially in view of the broad "exemption" in the Investment Company Act itself for companies with fewer than 100 shareholders where no public offering is contemplated.

\section{Securities Act of 1933}

The Small Business Investment Act contains a discretionary exemption which permits the SEC to exempt from the Securities Act of 1933 any class of securities issued by a small business investment company if it finds that enforcement of that act is "not necessary in the public interest and for the protection of investors." 124 Pursuant to this authorization, the SEC has adopted regulation $E,{ }^{125}$ which in general exempts from registration the securities of any SBI company when the aggregate offering price of the issue is not in excess of $\$ 300,000 . .^{120}$ The regulation instead requires the filing of a notification form with the $\mathrm{SEC}^{127}$ and in addition the filing and use of an offering circular, ${ }^{128}$ unless the aggregate offering price does not exceed $\$ 50,000$. In the latter case, 'no offering circular need be prepared, but the notification must be supplemented by information which would otherwise appear in the offering circular. ${ }^{129}$ Whether or not an offering circular is required, the issuer must file copies of its sales materials with the SEC. ${ }^{130}$ If at any time the SEC finds that an issuer has not complied with the terms or conditions of the regulation, the exemption may be suspended. ${ }^{131}$

Regulation $\mathrm{E}$ is similar in many respects to the general "small issue" exemption-not available to registered investment compames-of SEC Regulation A. ${ }^{132}$ Its justification lies in the heavy burden and expense of registration for the small issuer. At the same time, the required use of the notification statement and, more realistically, the offering circular may afford the investor some protection. Moreover, persons offering securities under an exemption are still subject to the antifraud provisions of the Securities Act. ${ }^{133}$

123 Senate Hearings 238.

124 SBI Act, § 307 (a), 72 Stat. 694 (1958), 15 U.S.C.A. $877 c(c)$ (Supp. 1958). A discretionary exemption was provided for because the Senate Committee on Banking and Currency felt that while an outright exemption would not be wise, the SEC might find justification for some exemptions that would be consistent with the purposes of the securities laws. SEN. CosrMITTEE REPORT 13.

125 SEC Reg. E, which will be 17 C.F.R. $\$ \$ 230.601-610 a$. Compare generally SEC Reg. A, 17 C.F.R. $\$ \$ 230.251-262$ (Supp. 1958).

126 SEC Reg. E (17 C.F.R. § 230.603).

127 SEC Reg. E (17 C.F.R. \& 230.604). This notification lists such matters as the name of the issuer, its officers, directors, and principal security holders, as well as the jurisdictions in which the securities are to be offered, and the authority under which the exemption from registration is claimed. Form 1-E, Securities Act Release No, 4005 and Investment Company Act Release No. 2805 (Dec. 17, 1958); CCH Fed. Securuties L. Rep. II 7351.

128 SEC Reg. E (17 C.F.R. $\$ 230.610 \mathrm{a}$ ). The infornation required to be specified in this circular relates to the management and financial condition of the issuer, including its business and investment policies. Appropriate financial statements encompassing a balance sheet and profit and loss or income statement must be included. These must be prepared in accordance with generally accepted accounting principles but need not be certified by independent public accountants. Ibid.

120 SEC Reg. E (17 C.F.R. \$ 230.606).

130 SEC Reg. E (17 C.F.R. \& 230.607).

131 SEC Reg. E (17 C.F.R. \$ 230.610).

13217 C.F.R. §§ 230.251-262 (Supp. 1958).

133 Securities Act of 1933, \& 17, 48 Stat. 84 (1933), 15 U.S.C. \& 77q (1952). 


\section{Trust Indenture Act of 1939}

If the small business investment company plans to issue debt securities, the Trust Indenture Act of $1939^{134}$ may also apply. Generally this act provides that debt securities can be offered or sold through the use of the inails or other interstate facilities only if issued under an indenture which meets the requirements of the act. These requirements relate prinarily to the enforceability of the security holders' rights by a quahified trustee or trustees, at least one of whom must be an institutional trustee possessing a minimum of $\$ 150,000$ capital and surplus. ${ }^{135}$ Exempt from the act are offerings of $\$ 250,000$ or less made during 12 consecutive months where the securities are not issued under an indenture, ${ }^{136}$ and offerings of $\$ 1$ million or less made in 36 consecutive months where the issue is under an indenture which limits the total issue to $\$ 1$ million. ${ }^{137}$ These rather large exenptions should effectively place the operations of most small business investment companies beyond the reach of the act. In addition the Small Business Investment Act allows the SEC to exempt any class of securities of a small business investment company from the provisions of the Trust Indenture Act, ${ }^{138}$ but no regulations have as yet been promulgated by the SEC under this authority.

\section{Tax Incentives to Investment}

Apart from any speculative attraction inherent in the nature of the mvestment, Congress concluded that certain tax advantages, both for the companies and their shareholders, would be necessary to initiate a flow of long term private capital into small business. These provisions-part of the Technical Amendments Act of $1958^{133}$ - were included in legislation which granted a number of new tax benefits to small business concerns themselves. ${ }^{140}$

From the investor's point of view one of the most attractive features of owning stock in the new companies is that he will be able to treat as an ordinary business loss any loss on their stock which, but for the new legislation, would be a loss from the sale or exchange of a capital asset. ${ }^{141}$

Other tax provisions, relating directly to the investment companies rather than to their shareholders, but providing additional incentive to investment, are discussed below in connection with the investment programs of SBI companies. ${ }^{142}$

\section{Operations: AID for Small Business}

The importance of the new act will depend not only on whether Congress has provided sufficient "fringe benefits" for investment in the SBI companies, but also on whether the operations of these companies, under the provisions of the act, will

13453 Stat. 1149 (1939), 15 U.S.C. $\$ \$ 77$ aaa-bbbb (1952).

135 Trust Indenture Act of 1939, § 310, 53 Stat. 1157 (1939), 15 U.S.C. \& 77jjj (1952).

136 Trust Indenture Act of 1939, § 304, 53 Stat. 1153 (1939), 15 U.S.C. § 77ddd(a) (1952).

137 Trust Indenture Act of 1939, §304(a), 53 Stat. 1153 (1939), 15 U.S.C. § 77ddd(a) (1952).

138 SBI Act, $\$ 307$ (b), 72 Stat. 694 (1958), 15 U.S.C.A. § 77ddd(e) (Supp. 1958).

13972 Stat. 1650 (1958).

140 See note 3 sucpra.

141 INT. Rev. CODE of $1954 \S 1242$, as added by the Technical Amendments Act of 1958, \$57(a), 72 Stat. 1645 (1958).

142 See text at notes 183-84, 194-207 infra. 
supply enough capital to small business ${ }^{143}$ to alleviate long term financing problems that have always been to some extent inherent in small business ventures.

\section{A. Financing Small Business}

SBI companies are to provide capital for small business operations, modernization and growth through a curious type of "equity" financing and by means of long term loans.

There is a general limitation, however, on financial operations of SBI companies which is implicit in the statement of policy in the act. The program is to be so administered that any financial assistance provided under it shall not result in a substantial increase of unemployment in any area of the country. ${ }^{144}$ This provision was designed to prevent federal funds from being used to subsidize the flight of industry from one section of the country to another, ${ }^{145}$ but has merely resulted in regnlations reiterating the statutory language; ${ }^{140}$ it seems that this

143 "Small business concern" under the new act, by virtue of $\S 103(5)$, is to have the same meaning as in the Small Business Act, 72 Stat. 690 (1958), 15 U.S.C.A. $\S 632$ (Supp. 1958), i.e., one independently owned and operated and not dominant in its field of operation.

A document prepared for the House committee states that $\$ 103(5)$ "means that whatever definitions the SBA has in effect for its regular loan program [under the Small Business Act] will also apply to the new program." House Select. Comm. on Small Business, 85th Cong., 2d Sess., How to Obtain Financing under the Small Business Investment Act of 1958-Questions and Answers in Simple Terms 31 (Comm. Print 1958) ; accord, CCH, SMart BusINEss INvesTMENT ACT WITH EXPLANation 6 (1958). This conclusion is not warranted by the statutory language. SBA indicates that its regulations "defining small business concerns for the purposes of the Small Business Act do not apply for the purposes of the Sinall Business Investment Act of 1958. In the latter case, the definition ... contained in Section 107.103-1 of the Regulations is controlling." Letter from Duncan $H$. Read, Deputy Administrator, Investment Division, SBA, to authors, February 26, 1959. This regulation makes no reference to the definition of small business in the Small Business Act regulations. It provides only that on a prima facie basis a concern is not small (1) if its stock is traded on an exchange or over-the-counter through brokers; (2) if it has sold its securities through a public offering within the preceding 3 years; or (3) if-in cases where it has no stock or where its stock has no public market-its total assets amount to over $\$ 5$ million or its net reported earnings, after taxes, have averaged over $\$ 150,000$ for the preceding 3 years. A concern is an affilitte and therefore not independently owned and operated (1) if it is a wholly owned subsidiary of another concern; (2) if it is under the control or potential control of another concern other than an SBI company; or (3) if it and another concern are both owned by a third party. A parent and its subsidiaries must be considered together in determining eligibility as a sinall business. A conceru which claims it is small notwithstanding these provisions may apply to SBA on SBA Form 355 for certification as a small busimess concern. SBA Regs. § 107.103-1.

For analyses of definitions of small business, see Dockery, What Is Small Business? New Rules, Dun's Review, May 1952; Federal Reserve Report 93, 150-71, 282, 364-66; Senate Hearings 51-52.

144 SBI Act, § 102, 72 Stat. 689 (1958), 15 U.S.C.A. \$ 661 (Supp. 1958).

145 The purpose of this proviso was stated by the Senate Committee on Banking and Currency as follows: "It is of no concern to the committee whether State or private funds are used to attract industry into a particular area, but it is the committee's intent that Federal funds shall not be used for such a purpose. Accordingly, the committee wishes to make it clear that the Small Business Administration should not provide any financial assistance under tbis act which may be used to provide a subsidy to mduce any relocation of industry or to assist any relocation of a small-business concern for other than a sound husiness purpose." SEN. CoMMITTEE REPORT 10. The language of the statute does not really justify this explanation; it docs not seem likely that the relocation of a small business would result in a "substantial increase of unemployment in any area of the country."

146 SBA Regs. \$ 107.102-1(g). Section 107.308-2(a) (5) adds that licensees shall not knowingly or intentionally employ SBA disbursed funds for any purnose which would cause a substantial increase of unemployment im any area of the country, although SBA indicated to Congress that conditions written into individual loans should be sufficient to prevent federal funds being used to subsidize relocations in different areas of the country. House Hearings 1004. 
objective is as difficult for SBA to translate into concrete regulations as it proved to be for Congress.

\section{1. "Equity" financing: section 304 convertible debentures}

In spite of the fact that Congress declared a primary function of each SBI company to be to provide a source of needed equity capital for small business concerns, ${ }^{147}$ ownership capital-properly speaking-can only be supplied by first purchasing convertible, callable "debenture bonds" of the small business, which may then be converted into stock. ${ }^{148}$ The reason for requiring two steps to reach a result better reached in one was that the sponsors of the legislation feared that congressional opponents of another "venture by the federal government into private business" 149 would reject any measure permitting federally financed investment companies to purchase a proprietary interest in private business. ${ }^{150}$ Nevertheless, since the act as approved contains no restrictions on immediate conversion by SBI compamies, it appears that the statutory procedure is a classic case of the rose by another name.

SBA originally undertook to provide by regulation what Congress did not see fit to require by statute; an SBI company indebted to SBA would not have been permitted to own stock having a value in excess of its private financing, except during liquidation of the company, and would have been required to dispose of any stock which was in any manner acquired in excess of the limitation, for cash, within sixty days of the date of the "imbalance," 151 under penalty of license forfeiture. ${ }^{152}$ Fortunately, SBA was persuaded to omit the provision from the final regulations. It would not have furthered the purposes of the act to force such prompt liquidation of stockholdings—often at unreasonably low prices because of lack of a market for SBI company portfolio securities. On the other hand, a restriction on the stockholders of only those investment companies indebted to the government would have been a somewhat more rational approach to indirect federal ownership of business than is a restriction which affects also those imvestment companies financed entirely by private funds, as does the statutory requirement that "equity" investments be initially in the form of convertible debentures.

The act provides that the debentures shall (1) bear interest at a rate fixed by

147 SBI Act, § 304(a), 72 Stat. 693 (1958), 15 U.S.C.A. § 684(a) (Supp. 1958) ; SBA Regs. $\S 107.304-1$.

148 SBI Act, § 304(b), 72 Stat. 693 (1958), 15 U.S.C.A. § 684(b) (Supp. 1958).

Senator Clark, chairman of the subcommittee, carefully distinguished the convertible debentures from equity securities, characterizing the debentures as debt instruments. E.g., Senate Hearings 376. The SEC was also of the opmion that "it does not seem appropriate to characterize the issuance of such debentures as equity financing." Senate Hearings 235,241 . The view of SBA Administrator Barnes as to the distinction between debt and equity is stated in House Hearings 1000-01, 1013. Bennett).

149 Sen. Commitree Report 19 (individual views of Senators Capehart, Bricker and

150 Senate Hearings 278-81 (comments of Senator Clark). Clark insisted that none of the proposals under consideration by the subcommittee permitted common stock investments by SBI companies, although he questioned the wisdom of such an investment limitation. Senate Hearings 279-81, 376-77. Nonetheless, the conversion feature was included in the debenture provisions at the time of his remarks.

151 Proposed SBA Regulation 107.306-1(c), 23 Fed. Reg. 8358 (1958).

152 SBA Regs. \$ 107.308-11. Administrator Barnes of SBA had opposed government stock ownership and, although SBI compames and not SBA would own any stock involved, had illogically supported convertible debentures as a means of avoiding it. House Hearings 1013. 
the SBI company with SBA approval; ${ }^{153}$ (2) be callable on any interest payment date, upon three months' notice, at par plus accrued interest; ${ }^{154}(3)$ be convertible at the option of the issuer or a holder in due course up to and including the effective date of any call by the issuer, into stock of the small business concern at sound book value of such stock determined at the time the debentures are issued;155 and (4) contain such other terms as the investment company may fix with SBA approval..$^{156}$

In addition to the prescribed features of the debentures, the act permits SBI companies to require the small business to refinance any or all of its outstanding indebtedness so that the SBI company is the only holder of any evidence of indebtedness of the small concern. ${ }^{167}$ Regulations, however, permit two or more SBI companies to participate in the purchase of the debentures. ${ }^{158}$ The act requires the small business to agree that it will not incur any indebtedness without prior approval of the investment company and without giving the company the first opportumity to finance the new indebtedness. ${ }^{150} \mathrm{SBA}$ may by regulation provide exceptions to this requirement; ${ }^{160}$ the only exceptions presently in the regulations are for open book and other short term credit. ${ }^{11}$

The act requires small businesses financed under section 304 to become shareholders in the SBI company concerned by investing in the company's capital stock an anount equal to from two to five percent of the capital provided by the company through the debenture medium, in accordance with SBA regulations. ${ }^{102}$ The regulations provide that the price per share of the stock will be established by the

153 SBI Act, § 304(b) (1), 72 Stat. 693 (1958), 15 U.S.C.A. \& 684(b) (1) (Supp. 1958).

154 SBI Act, $\$ 304$ (b) (2), 72 Stat. 693 (1958), 15 U.S.C.A. $\$ 684$ (b) (2) (Supp. 1958).

105 SBI Act, $\$ 304$ (b) (3), 72 Stat. 693 (1958), 15 U.S.C.A. \$ 684(b) (3) (Supp. 1958).

156 SBI Act, $\S 304$ (b) (1), 72 Stat. 693 (1958), 15 U.S.C.A. \& 684(b) (1) (Supp. 1958).

SBA Regs. $\$ \$ 107.304-1(\mathrm{~b})-(\mathrm{h})$, pursuant to these provisions of the act, answer some questions but raise others. SBA regulations approve interest charges up to the local legal limit applicable to the debenture transaction; where there is no applicable legal limit, maximum interest charges must be approved by SBA. $\$ 107.304-1(f)$. Regulations concerning the call feature add little to the provisions of the act. See $\$ 107.304-1(\mathrm{~b})$. Regulations concerning the conversion feature provide that the sound book value of stock into which debentures may he converted-determined at the time of issuance of the debentures-inust he calculated on the basis of a consideration of all pertinent factors including actual value of assets of the small business and the relationship of earnings to invested capital. $\$ 107.304-1$ (c), (d).

Although $\S 304(\mathrm{~b})$ (1) of the act indicates that SBA must approve all other terms of the debentures, regulations indicate SBA will deem the requirement satisfied if the proposal for licensing sets forth standard provisions, including pricing policy, for its approval. SBA Regs. $\$ 107.304-1(i)$; see items 12, 13, SBA Form 414. Thereafter, "under tbe free principles of the market place," licensees and small business concerns may negotiate the specific terms of particular transactions, and only in the event that the terms constitute "a major variance" from the policies of the licensee stated in its proposal, will specific approval be required. SBA Regs. \$ 107.304-1(i). The SBI companies, under this arrangement, determine what constitutes "inajor variance" in the normal case. The procedure may render the statutory language nugatory. SBA should require periodic reports of the material terms of SBI company transactions, to retain some control over the companies and to discourage abusive practices.

157 SBI Act, \$ 304(c) (1), 72 Stat. 693 (1958), 15 U.S.C.A. \$ 684(c) (1) (Supp. 1958).

158 SBA Regs. \& 107.304-1(e).

159 SBI Act, \& 304(c) (2), 72 Stat. 693 (1958), 15 U.S.C.A. § 684(c) (2) (Supp. 1958).

160 Ibid.

161 SBA Regs. $\S 107.304-1(\mathrm{~g})$.

162 SBI Act, \& 304(d), 72 Stat. 693 (1958), 15 U.S.C.A. § 684(d) (Supp. 1958). Nothing in the act or regulations prevents creation of a special class of stock for this purpose or spells out what rights such stock must have. Section 304(d) requires only that the small business become a "stockholder-proprietor" through the stock purchase. 
SBI company with concurrence of the small business ${ }^{163}$ - when the price is to be determined is not specified. The purchase shall be simultaneous with each delivery of and payment for debentures in full or partial performance of the agreement between the parties, ${ }^{164}$ and shall be in certain stated amounts, ${ }^{165}$ within the statutory limits.

The purpose of the stock purchase requirement "is to build up the investment of private funds and, in due course, to make federal participation unnecessary," according to the Senate Select Committee on Small Business. ${ }^{166}$ Why the requirement, then, should apply equally to companies already entirely financed with private funds was not explained. Consistent with this legislative objective, if not with the statutory requirement, SBA permits licensees not indebted to it to issue such stock with a repurchase option to be exercised in not less than thirty days at the price paid per share; other licensees may not repurchase the stock as long as they remain indebted to SBA. ${ }^{167}$ The small business concern may sell the stock to others at any time, except when a repurchase option precludes it. ${ }^{168}$

Issuance of small business debentures to SBI companies should not itself require registration under either the 1933 or 1939 acts, since normally the issue will not constitute a public offering 169 but rather "an isolated sale of ... . securities to a particular person"170 - unless the SBI company intends to resell the securities, bemg in effect an underwriter, or unless the portfolio transactions constitute it a dealer, under the acts. ${ }^{171}$ But with respect to the cross-purchase of the investment company's shares, the picture becomes more complicated. The 1933 and 1940 acts and exemptions thereunder, discussed generally above, must be considered, and pertinent is the further question whether these cross-purchases should not also qualify for the private offering exemption from the 1933 act ${ }^{172}$ and, for investment companies with fewer than 100 shareliolders, from the 1940 act. ${ }^{173}$ The SEC has just adopted a new regulation providing that an offer or sale of stock of a licensed SBI company to a small business pursuant to section 304 debenture transactions shall not constitute a "public offering" under either act, provided that the SBI stock is purchased by the small business for investment and not with a view to its distribution. ${ }^{174}$ Whether the proposal is wise is debatable, especially in view of the earlier and apparently sound view of the SEC that "there is nothing

163 SBA Regs. $\$ 107.304-1(\mathrm{~h})$.

164 lbid.

165 Two percent of the first $\$ 50,000$ of debentures purchased; three percent of the next $\$ 50,000$; five percent of amounts over $\$ 100,000$. Ibid.

160 Sen. Select Comanttee Print 17; see also Sen. Comanttee Report 12.

187 SBA Regs. $\$ 107.304-1(\mathrm{~h})$.

108 Ibid.

169 Securities Act of 1933, $\$ 4(1), 48$ Stat. 77 (1933) as amended, 15 U.S.C. \& 77d(1)

(1952); Trust Indenture Act of 1939, § 304(b), 53 Stat. 1153 (1939), 15 U.S.C. \$77ddd(b)

(1952); Senate Hearings 235 (statement of Edward N. Gadsby, Chairman, SEC).

170 H. R. REP. No. 85, 73d Cong., 1st Sess. 15-16 (1933).

171 See Loss, SECURITIES REgulation 398 (1951). These problems are discussed more fully in the text following note 214 infra.

172 Securities Act of $1933, \S 4(1), 48$ Stat. 77 (1933), as amended, 15 U.S.C. $\$ 77 d(1)$ (1952).

173 Investment Company Act of 1940, \& 3 (c) (1), 54 Stat. 798 (1940), 15 U.S.C. $\$ 80 a-$

3 (c) (1) (1952); commented on by SEC Cbairman Edward N. Gadsby, Senate Hearings 237.

174 Securities Act Release No. 4033 (Feb. 13, 1959) (Rule 151); Investment Company Act

Release No. 2828 (Feb. 13, 1959) (Rule N-3C-1). 
to demonstrate the fact that these small business concerns are any less in need of [protection] than other investors." 175

Whether or not the issue of debentures will be subject to SEC regulation under the federal securities statutes, state Blue Sky laws-for instance California'smay still apply to the transaction. That the SBI company has a federal charter is immaterial, for in any case, the exemption from its Securities Law which California grants federally chartered companies ${ }^{176}$ clearly does not extend to the small busimess issuers. The speculative character of the debentures ${ }^{177}$ may justify the Corporation Commissioner in requiring a deposit of the securities in escrow, ${ }^{178}$ so that they cannot be peddled to an unwary public. The Commissioner's regulations also indicate that he views with disfavor any debenture transaction not backed by sufficient equity, without escrow of the debentures. ${ }^{178}$

In spite of the indirection of the procedure by which SBI companies may furnish "equity" funds to small businesses, the legislation should have some value in filling the institutional gap in this type of financing, since it provides a way to reduce the cost of equity capital for small business, where a public distribution of securities would otherwise be necessary. ${ }^{180}$ On the other hand, it is uncertain whether the SBI company device will prove to have any real advantage over existing opportunities for private placement of entire issues. ${ }^{181}$ It may be that SBI companies will be organized by large concerns to finance customers and distributors, ${ }^{182}$ and that the debenture device will prove to be most frequently used by such companies, in situations where the small business would have been willing to permit the other party to the transaction to buy into a stock position without benefit of the new legislation.

Of course, SBI companies will be organized to mvestigate investment possibilities as economically as possible and may eventually be able to do so at a lower cost than can existing investment banking houses concerned primarily with the prob-

175 Senate Hearings 48.

If the SBI company undertakes to finance qualified small businesses in general, of necessity it offers its securities to a class composed of numerous persons, as many as there are small businesses within its area of operation, since a condition of $\$ 304$ financing is the cross-purchase. The number of offerees should itself militate against the exemption. See Loss, SEcururies RecULATton 396 (1951). More important, whether the class needs protection is highly relevant, under SEC v. Ralston Purina Co., 346 U.S. 119 (1953). Although the SBI company furmishes the small business the wherewithal for the purchase, the small business must assume the obhigation of the debentures-it clearly pays for the stock it purcbases. There is nothing to indicate that these small busimess concerns will be any better informed or more sophisticated and therefore less in need of protection under the SEC administered statutes than other investors in general.

176 CAT. CORP. CODE $\S 25100(c)$.

177 See text at notes 208-12 infra.

178 See Cal. CoRp. Code $\S 25508 ; 10$ Cad. Admin. Code $\S 407$. The speculative nature of a venture is one of the most common reasons for the Commissioner to impose conditions in a permit to issue securities designed to make issuance fair, just and equitable to all security holders who may be affected. Jennings, The Role of the States in Corporate Regulation and Investor Protection, 23 LAW \& ConTEMr. PROB. 191, 215 (1958).

17010 Car. Admin. Code $\$ \S 480-81$; 407. The 4:1 debt-capital ratio allowed by SBA must, in California, be considered with these regulations in mind.

180 Senate Hearings 222-25 (Weissman); FeDERAI Rrserve Report 110, 282-305. The cost factor is such that investment bankers ordmarily will not undertake public issues under $\$ 500,000$ to $\$ 1$ million. Id. at 334,365 .

181 Costs of private placement of small issues are inuch lower than are costs of public sale, but they are still higher than similar costs of large issues. Fr.derar REserve Report 305.

182 See CCH, Small Business Investment Act Wrtt Expeanation 7 (1958). 
lems of large issuers. SBI coinpanies should also becoine more adept at sizing up small business prospects.

Congress felt, however, that the conversion feature of the debentures was not a sufficient incentive to stimulate this type of investment. Additional incentives took the form of special tax provisions.

Any loss incurred by an SBI company on the convertible debentures or stock of small businesses acquired pursuant to section 304 of the act will be treated as a loss from the sale or exchange of property not a capital asset. ${ }^{183}$ The privilege of so treating losses on these securities is extended only to SBI companies; other taxpayers who become owners of such securities subsequent to an SBI coinpany inust treat losses thereon in the usual fashion. ${ }^{184}$

Congress also granted SBI companies a 100 percent dividends received deduction, ${ }^{185}$ considered more fully hereafter.

\section{Long term loans: section 305 transactions}

In addition to "equity" financing of sinall business, previously described, the new legislation provides for long term loans by SBI companies to sinall concerns -both incorporated and unincorporated. ${ }^{186}$ Congress concluded that sinall business had two distinct needs-i.e., for equity capital and for long term credit. The Senate subcommittee which conducted hearings on the legislation heard much testimony that small businessmen in need of long term funds do not wish to share their ownership with outsiders in order to finance expansion and modernization; often, they will forego an expansion if credit cannot be obtained. ${ }^{187}$ On the other hand, it has been suggested that small businesses frequently cannot get loans because the loans would not be sufficiently protected by underlying capital - that is, equity is often too thin to justify further debt. ${ }^{188}$ The problem is only aggravated where long terin debt is sought, suggesting, therefore, that perhaps a large part of

183 Int. REv. CoDe of 1954 as amended, $\S 1243$, added by Technical Amendments Act of $1958, \S 57$ (a).

184 Ibid.

185 INT. Rev. CoDE of 1954 \$243, as amended hy Techmical Amendments Act of 1958 $\S 57$ (b), 72 Stat. 1645 (1958).

186 SBI Act, $\$ 305$, 72 Stat. 693 (1958), 15 U.S.C.A. § 685 (Supp. 1958). Terms and conditions: interest may not exceed the apphicable maximum rate under local law. In the absence of a local maximum, SBA will determine the rate. Maturities may not be in less than 5 nor more than 20 years, except that loans for terms under 5 years may be made to enterprises already financed by the SBI company through $\$ 305$ loans or $\$ 304$ debentures or stock, when necessary to protect the company's mterest in such loans, debentures or stock. Extensions and renewals, not exceeding 10 years, are permitted if the company finds the extension or renewal will aid in orderly hquidation of the loan. Payment of all or any part of the loans may be anticipated on any interest payment date. SBI Act, $\$ 305,72$ Stat. 693 (1958), 15 U.S.C.A. § 685 (Supp. 1958); SBA Regs. \$ 107.305-1.

The loans must also be "of such sound value or so secured as reasonably to assure payment." SBI Act, § 305 (e), 72 Stat. 694 (1958), 15 U.S.C.A. § 685(e) (Supp. 1958). (Emphasis added.) The same phrase, except for the word "such," appeared in the loan provisions of the Small Business Act of 1953, 67 Stat. 233 (1953). Although the provision was subject to construction as stating requirements in the alternative, SBA required collateral for all loans made under the program. See FEDERAI RESERVE REPORT 264. Addition of "such" appears designed to avoid this result under the SBI Act-SBI compamies should he permitted by SBA to lend money without collateral where repayment is otherwise reasonably assured.

187 E.g., Senate Hearings 173 (Robbins), 178 (Capehart), 206-07 (Flora), and passim; but see 185 (Clark), 347 (McCormick). See also FEDERAL RESERVE REPORT 145, 149, and passim. 188 E.g., Senate Hearings 174 (Robbins). 
this "credit gap" cannot properly be filled by private capital. ${ }^{180}$ Supporting this view, the SEC flatly opposed any provision for debt financing of small businesses unable to raise debt capital through conventional means. ${ }^{100}$ Whether the loan provisions of the new legislation will prove particularly valuable is therefore at present debatable.

A few problems respecting this lending power may arise under state law. Whether the power will subject the companies to regulation by authorities vested with regulatory power over lending institutions must be determined in each state. ${ }^{101}$ Also, state Blue Sky laws and regulations affecting the lending power of particular issuers of securities must be observed by SBI companies operating under state charters. ${ }^{102}$

\section{Tax aspects ${ }^{193}$}

The taxation of SBI companies raises the complicated question whether they qualify for taxation as regulated investment companies. In the Technical Amendments Act of 1958, Congress provided a 100 percent dividends received deduction for the SBI companies. ${ }^{194}$ Income from interest and capital gains is evidently to be taxed to SBI companies as it is to ordinary business corporations, unless they are to be permitted to qualify for deductions allowed regulated investment companies. This last possibility seems nowhere to have been fully explored.

The taxation of regulated investment companies follows a pattern ${ }^{105}$ more favorable to the imvestment company and its shareholders than will be the taxation of an SBI company forced to rely solely on the new 100 percent dividends received deduction. The Code permits the regulated companies to avoid the double tax almost entirely, on capital gains and interest as well as on dividends. ${ }^{196} \mathrm{It}$ is strange that Congress departed from this pattern, ${ }^{107}$ since it saw fit to grant so many other tax advantages to investments in SBI company stock.

Regulated investment companies, by virtue of their election to become such, lose the dividends received deduction. ${ }^{198}$ Instead, if they distribute 90 percent of non-capital gains income, ${ }^{199}$ they are permitted two clividends paid deductions: one offsets non-capital gains income to the extent of regular dividends paid in accordance with sections 561-63 of the Code, ${ }^{200}$ and the otler offsets capital gains

189 Also supporting this conclusion was the opinion of one witness that businessmen who seek loans for expansion and modernization unsupported by adequate equity really want "heads I win, tails you lose" deals-they ask others to assume risks of ownership while they retain control of the business and harvest any profits of success-and that a "need" of this kind should concern no one. Senate Hearings 347 (McCormick).

190 Senate Hearings 46.

101 See note 31,2 d para., suppra.

192 E.g., 10 CAL. ADMON. CODE $\$ 560$ (e) prohibits loans by open end investment companies. Federally chartered companies are generally exempt from the provisions of state Blue Sky laws, by terms of the Blue Sky law itself, as by CAL. CORP. CODE $\$ 25100$ (c).

193 Ordinary loss treatinent of losses sustained by SBI companies on $\$ 304$ debentures and stock is discussed in the text at notes 183-84 supra. Ordinary business loss treatment of losses sustained by shareholders on SBI company stock is discussed in the text at note 141 supra.

194 Technical Amendments Act of 1958, \& 57(b), amending INT. REv. CODE of $1954 \S 243$.

195 INT. REv. CODE OF $1954 \S 852$ (a), (b).

198 See text following note 198 infra.

197 Taxation of investment companies under two carlier bills would have been based explicitly on the provisions of the Code applicable to regulated investment comparies. See note 108 supra.

198 INT. REv. CODE OF $1954 \$ 852$ (b) (2) (C).

199 INT. REV. CODE OF $1954 \$ 852$ (a) (1).

200 INT. REv. CODE OF 1954 § 852 (b) (2) (D). 
to the extent of earmarked capital gains dividends ${ }^{201}$ paid to shareholders, again in accordance with sections 561-63. ${ }^{202}$ The effect of these provisions is to permit regulated investment coinpanies to avoid the income tax by distributing to shareholders substantially all income received.

The only apparent reason for departing from the pattern of the regulated investment company tax provisions is that those provisions force investment companies to distribute nearly all of their income. Congress may have intended SBI companies to build capital through retention of earnings, yet it failed to relieve the companies from the accumulated earnings and personal holding company provisions of the Code. ${ }^{203}$

In its early years, an SBI company will receive most of its income in interest and a small balance in capital gains. Until it has acquired substantial stockholdings througli conversion of section 304 debentures, the 100 percent dividends received deduction will have relatively little value, and even when its dividend income has grown, taxable interest and capital gains will continue to contribute significantly to total imcome. The question obviously arises, can SBI companies elect taxation as regulated investment companies, foregoing whatever limited value the dividends received deduction may have?

Only one of the requirements for qualifying as a regulated investment company ${ }^{204}$ appears to present real difficulties. Fifty percent of the assets of regulated investment companies nust be represented by cash, cash items including receivables, government securities, regnlated investment company securities, and-most important in the typical investinent company portfolio-otlrer securities. ${ }^{205}$ The other securities inust be limited, in respect to any one issuer, to an amount not greater in value than 5 percent of the taxpayer's total assets and to not more than 10 percent of the outstanding securities of the issuer. ${ }^{208}$ Therefore, to qualify as a regulated investment company, an SBI company cannot approach the aggregate statutory 20 percent himitation on investment of its assets in any one concern, ${ }^{207}$ except perhaps througl loans-the securities of any single concern held by the investment company cannot exceed 5 percent of its assets. More difficult to comply with is the 10 percent limitation; the value of debentures purchased by an SBI company may not exceed 10 percent of the outstanding securities of the small business. More substantial financing would require the participation of other SBI companies or outsiders, so that the purchase by each SBI company involved would be within the limitation. It seems clear, however, that many SBI companies simply will not be able to qualify for taxation as regulated investment companies because of the 10 percent rule.

\section{Resales of portfolio securities}

The fact that SBI companies may resell portfolio securities to outsiders raises some dangerous possibilities, from the point of view of investor protection.

\footnotetext{
201 INT. REv. CODE OF 1954 § 852 (b) (3) (C).

202 INT. REV. CODE OF $1954 \S 852$ (b) (3) (A).

203 See text at notes 52-53, 107-11 supro.

204 Requirements for regulated investment company status under the Code are in IrT. REv. CODE OF $1954 \S 851$.

205 INT. REV. CODE OF 1954 \& 851(b) (4) (A).

200 INT. REv. CODE OF $1954 \S 851$ (b) (4) (A) (ii). A different rule, which may apply to some SBI companies, is in INT. REv. CODE OF 1954 \& 851 (e), applicable to certain investment companies furnishing capital to enterprises principally engaged in development or exploitation of inventions, technological improvements, new processes, or products not previously generally available.

207 SBI Act, § 306, 72 Stat. 694 (1958), 15 U.S.C.A. § 686 (Supp. 1958).
} 
The portfolios of SBI companies will necessarily include many securities of an extremely speculative type. In the first place, they will represent the obligations or stock of small enterprises, which in itself introduces a high degree of risk..$^{208}$ Secondly, the cost of processing and investigating a proposal for a debenture transaction is likely to be relatively higher, the smaller the transaction involved;200 the high cost of processing small transactions such as those in which SBI companies will engage may require that any debentures purchased present a corresponding prospect of unusually high return-in other words, the venture must be speculative. Finally, as the SEC pointed out to the Senate, default is a very real possibility if small businesses engaged in speculative enterprises are allowed debt financing when they cannot raise debt capital by conventional means. ${ }^{210} \mathrm{It}$ would, of course, be unfortunate if these investment companies were permitted to unload such debt instruments on the public whenever a danger of default became apparent. Both the SEC ${ }^{211}$ and proponents of the legislation ${ }^{212}$ recognized the speculative character of these portfolio securities.

That SBI companies may resell these securities is clear. The act contains no restrictions on such resales-in fact it is entirely silent on the subject. ${ }^{213}$ Institutional resales present no particular problem of investor protection, but if the securities are to be offered to the public provision for its protection is necessary. This protection is afforded by existing federal and state securities laws and regnlations; the new legislation provides no exemption from the federal securities laws for these portfolio sales. ${ }^{214} \mathrm{~A}$ few aspects of those laws not already discussed are pertinent here:

1. If at the time of purchase an SBI company intends a "distribution" of the securities-that is, if it intends to resell to the public or otherwise to dispose of the securities so that what amounts to a public offering may result-it is an "underwriter" and accordingly must require registration of the issue. ${ }^{215}$ And if its portfolio sales constitute it a "dealer" under the 1933 act-one who engages directly or indirectly in the business of offering, buying, selling or otherwise dealing or

208 Federat Reserve RePort 46-50, 91-92; Senate Hearings 224 (Rudolph L. Weissman, W. E. Hutton \& Co.), 308 (C. Cheever Hardwick, member, Finance Committee, U. S. Chamber of Commerce). There are no exemptions for small issues or private offerings under the California Corporate Securities Law, because such exemptions are inconsistent with the purpose of the statute, investor protection. See Jennings, The Role of the States in Corporate Regulation and Investor Protection, 23 LAw \& Contexrp. Prob. 191, 217-18 (1958).

209 FEDERAT RESERVE REPORT 141, 289, 305.

210 Senate Hearings 46.

211 Ibid.

212 E.g., Senate Hearings 308 (Senators Clark and Proxmire).

$213 \mathrm{~A}$ proposed regulation which SBA finally dropped would bave required resale in one instance. See Proposed SBA Regulation 107.306-1(c), 23 Fed, Reg. 8358 (1958), discussed at note 151 supra.

214 Whether this protection is adequate raises questions that go to the basic philosophy of securities regulation and investor protection-whether disclosure is adequate for speculative deals-and the question of exemptions for small issues. See generally, Jennings, The Role of the States in Corporate Regulation and Investor Protection, 23 LaW \& ConTEMr. PRoB. 193, 207-30 (1958); as to small issues, Id. at 217-18; Loss, Sicuruties Regulation 76-82; SEC, Report on Proposats for AMENDMENTS to the Securities Act of 1933 aNd tHe Securities Exchange Act of 1934, 71st Cong., 1st Sess., 17 (H.R. Comm. Print 1941) ("the evils of high pressure salesmanship and of selling on the basis of inadequate information are particularly prevelant in small issues").

215 Securities Act of 1933, $\$ 2(11)$, 48 Stat. 75 (1933), 15 U.S.C. $\$ 77 b(11)$ (1952); sec Loss, Securities Regulation 342-50 (1951). 
trading in securities issued by another person ${ }^{216}$-it must require registration before it may resell the securities during the year following issuance or during any longer period in which its operations continue to bring it within the statutory definition. ${ }^{217}$ The SEC has stated that it approves this application of the 1933 act to SBI companies. ${ }^{218}$

2. The same conduct-regular selling of portfoho securities-that may make necessary registration of particular SBI company portfolio securities will also generally place the SBI company within the definition of "dealer" in the Securities Exchange Act of $1934 .{ }^{210}$ The company must then comply with the provisions of section 15 of that act, including the registration requirement.220

3. Under some state Blue Sky laws, the state securities authorities may have power to supervise any resale of portfolio securities-for example, in states where the original permit to issue can be conditioned on an escrow of the certificates. ${ }^{221}$ As has been indicated, it seems likely for more than one reason that section 304 debentures will receive close scrutmy from the California Corporation Counmissioner. ${ }^{222}$

\section{B. Advisory Services}

Studies have indicated that undermanagement and uneven managerial experience are important factors contributing to the institutional gap. ${ }^{223}$ Investment and commercial banking institutions will not advance funds to improperly managed concerns, nor can they often afford to engage in management directly or to provide sufficient advisory services to remedy managerial defects. ${ }^{224}$ Perhaps as important in the long run as the provisions for direct financing of small businesses is the provision in the new legislation authorizing SBI companies to provide consulting and advisory services on a fee basis and to have on their staffs persons competent to provide such services. ${ }^{225}$ Also, Congress provided that SBI companies may make use of the advisory services of the Federal Reserve System and of the Department of Commerce where practicable and where useful to industrial and commercial business. ${ }^{226}$

The act provides that the operations of an SBI company, including the generation of business, may be undertaken in cooperation with banks or other finan-

216 Securities Act of 1933, $\$ 2(12), 48$ Stat. 75 (1933), 15 U.S.C. $\$ 77 b(12)$ (1952); see Loss, Securities Regulation 350 (1951).

217 See Loss, Securities Regulation 124 (1951).

218 Senale Hearings 46, 241.

${ }^{210}$ Securities Exchange Act of 1934, $\S 3$ (a) (5), 48 Stat. 883 (1934); 15 U.S.C. $\$ 78 c$ (a) (5) (1952).

220 Securities Exchange Act of 1934, § 15, 48 Stat. 895 (1934) as amended, 15 U.S.C. $\$ 780$ (1952).

221 E.g., CAL. CoRP. CODE $\$ 25508$; see generally Jennings, The Role of the States int Corporate Regulation and Investor Protection, 23 LAw \& ConTEMr. ProB. 193, 214-16 (1958).

222 See text at notes 177-79 supra.

223 Senate Hearings 383 (George); Federal Reserve RepORT 334. For a discussion of management problems of small manufacturing enterprises in relation to financing, see $I d$. at 322-35. Undermanagement is the greater risk factor in small busmess financing, and therefore the most important reason why small businesses have difficulty raising capital. Id. at 334. Bank industrial loan experience indicates that managerial assistance is an integral and, perhaps, essential part of successful bank management of small-loan portfolios. Roosa, Some Small Business Problens Indicated by the Industrial Loan Experience of the Federal Reserve Bank of New York, Jour. of Fimance, April $195 \%$.

224 Senate Hearings 296 (Hardwick).

225 SBI Act, § 308(b), 72 Stat. 695 (1958), 15 U.S.C.A. \& 687(b) (Supp. 1958).

220 Ibid. 
cial institutions, and any servicing or initial investigation required for loans or acquisitions of securities by the company under the provisions of the act may be handled through such banks or other financial institutions on a fee basis. SBI companies may also receive fees for services rendered to banks or other financial institutions. ${ }^{227}$

SBA originally included a provision in its regulations to the effect that without its prior written approval, no SBI company inight contract or otherwise deal with any investment advisers. ${ }^{228}$ The provision was omitted from the final regulations -drawing a line between "financial institutions" and "investment advisers" proved too complicated. The objective of the proposed regulation was sound, however, for the investment advisory field is still fertile for the unscrupulous and the incompetent.

\section{ConCluston}

While some of the problems arising under the act and regulations will be difficult to solve, they do not seem to be of a nature to call into question the basic value of the new legislation. Rather, its value will depend on the accuracy of the congressional determination that small business needs more long term capital than is presently available to it, and that this need can be filled profitably by private capital with a minimum of federal assistance.

William John Martin, Jr. Ralph J. Moore, Jr. 